\title{
$543 \mathrm{~nm}$ 헬륨네온 레이저의 주파수 안정화를 위한 $\mathrm{I}_{2}$ 포화흡수분광 \\ 김경찬 ${ }^{*^{*}}$, 엄년식 ${ }^{2}$, 홍주현 $^{2}$, 서호성 ${ }^{3}$ \\ ${ }^{1}$ 계명대학교 자연과학대학 화학과, ${ }^{2}$ 계명대학교 의료기기인력양성센터, ${ }^{3}$ 한국표준과학연구원 길이시간센터
}

\section{$\mathbf{I}_{2}$-Saturated Absorption Spectroscopy for Frequency-Stabilization of He-Ne Laser at $543 \mathrm{~nm}$}

\author{
Kyung-Chan Kim ${ }^{1 *}$, Nyeon-Sik Eum ${ }^{2}$, Joo-Hyun Hong ${ }^{2}$ and Ho-Sung Seo ${ }^{3}$ \\ ${ }^{1}$ Dept. of Chemistry, Keimyung University, \\ ${ }^{2}$ Center for IT-Medical Device Convergence, Keimyung University, \\ ${ }^{3}$ Korea Research Institute of Standards and Science
}

요 약 본 연구는 $543 \mathrm{~nm}$ 헬륨네온 레이저의 주파수 안정화를 위한 ${ }^{127} \mathrm{I}_{2}$ 포화흡수분광 장치의 설계와 제작에 관한 것이다. 온도와 PZT 변화에 의한 레이저관 길이 가변을 이용하여 $543 \mathrm{~nm}$ 헬륨네온 레이저의 주파수를 주사시켰다. 3 차 고조파 신호을 얻기 위해 PZT 변조 가능한 레이저 출력경을 이용하여 주파수 변조를 하였다. 그 결과, ${ }^{127} \mathrm{I}_{2}$ 용 $\mathrm{B}-\mathrm{X}$ 시스템의 R(12) 26-0에서 R(106) 28-0의 천이를 가지는 초미세구조 분광은 포화흡수분광기를 사용한 3차 미분 신호에서 관찰되었다. 또한, 전형적인 초미세구조 분광 신호의 신호대 잡음비는 약 $30: 1$ 로 얻어졌다.

\begin{abstract}
We have designed and assembled a saturated absorption-spectroscopy system of ${ }^{127} \mathrm{I}_{2}$ for the frequency stabilization of the $543 \mathrm{~nm}$ He-Ne laser. The frequency of a internal-mirror $543 \mathrm{~nm} \mathrm{He}-\mathrm{Ne}$ laser was swept by utilizing the temperature and PZT change of the laser cavity length. Frequency modulation was applied to the output laser mirror with a PZT modulator for the third harmonic signal. A portion of the hyperfine spectrum originated from the $\mathrm{R}(12) 26-0$ and $\mathrm{R}(106) 28-0$ transitions of the $\mathrm{B}-\mathrm{X}$ system of ${ }^{127} \mathrm{I}_{2}$ was observed as the third-derivative signal using a saturated absorption spectroscopy. The signal-to-noise ratio of a typical hyperfine spectrum signal was estimated to be $30: 1$.
\end{abstract}

Key Words : $543 \mathrm{~nm}$ He-Ne Laser, Frequency Stabilization, Hyperfine Spectrum, Absorption Spectroscopy

\section{1. 서론}

$543 \mathrm{~nm}$ 헬륨네온 레이저는 $633 \mathrm{~nm}$ 의 헬륨네온 레이 저에 비해, 이득이 $1 / 20$ 배로 작고 또한 파장이 짧으므로 산란에 의한 반사손실이 커서 레이저 개발이 쉽지 않았 다. 1985년에 Perry에 의해 레이저 발진이 처음으로 보고 되었으나 그 이후 상용으로의 개발이 잘 이루어지지 않 았다. 그러나 최근에 전자빔에 의한 다중 증착기술의 발
달로 저손실-파장 선택형 고반사율의 반사경 제조 기술 과 고기밀(hard seal) 레이저관 제조 기술이 크게 개선됨 에 따라 저이득에서도 레이저가 오랫동안 안정하게 발진 하게 되었으며 상용화가 이루어졌다[1]. 이에 따라 이미 잘 알려진 요오드 분자의 녹색 초미세 흡수분광선에 맞 추어 $543 \mathrm{~nm}$ 헬륨네온 레이저의 안정화가 활발하게 연 구되었다.

1986년에 BIPM의 J. M. Chartier 등이 처음으로 파수

본 연구 과제는 계명대학교 비사연구비 지원으로 수행되었습니다. 연구비 지원에 감사드립니다.

"교신저자 : 김경찬 (kyung@kmu.ac.kr)

접수일 09년 10월 09일

수정일 (1차 10 년 02 월 18 일, 2 차 10 년 03 월 10 일)

게재확정일 10 년 03 월 18 일 
$18398.72 \mathrm{~cm}^{-1}$ (f = $551579749.3 \mathrm{MHz}, \lambda=543516$ $070.7 \mathrm{fm})$ 에서 요오드 분자 $\left({ }^{127} \mathrm{I}_{2}\right)$ 의 미세구조선인 $\mathrm{R}(12)$ 26-0과 R(106) 28-0이 $543 \mathrm{~nm}$ 의 녹색 레이저파장과 잘 일치함을 $543 \mathrm{~nm}$ 파장의 헬륨네온 레이저를 이용한 포 화흡수 분광실험에서 1차 고조파 신호 검출을 통해서 밝 혀내었다[2]. 이후 많은 연구그룹들이 각종 안정화 기법 을 도입하여 $543 \mathrm{~nm}$ 헬륨네온 레이저의 주파수 안정화 를 연구하였다. 3차 고조파를 이용한 포화흡수 분광법[3], $\mathrm{FM}$ 초고감도 분광법[4], 2중 차분 포화흡수 분광법[5] 등 을 이용하여 요오드 분자의 초미세구조선의 포화흡수신 호에 주파수를 안정화시킨 레이저를 개발하였다.

이들 레이저 사이의 주파수 안정도와 주파수 옵셋 (offset) 등 각종 주파수 특성 측정연구를 수행한 결과, 파 장 $543 \mathrm{~nm}$ (요오드 분자의 진동전이선 26-0, 회전전이선 $\mathrm{R}(12)$, 초미세구조선 $\left.\mathrm{a}_{9}\right)$ 에서의 파장 $(\mathrm{f}=551579$ $482.96 \mathrm{MHz}, \lambda=543516333.1 \mathrm{fm}$, 불확도 $2.5 \times 10^{-10}$, 요오드 셀의 냉지 온도 $\left.(0 \pm 2)^{\circ} \mathrm{C}\right)$ 이 1992년 제 8 차 미터 정의 자문회의에서 미터 현시를 위한 표준파장으로 추천 되었다[6].

그러나 국내에서는 국가표준을 위한 $543 \mathrm{~nm}$ 레이저의 주파수 안정화에 관한 연구가 아직 보고된 바 없으므로, 이에 대한 연구가 필요하다. 본 연구에서는 이미 본 연구 팀에 의해 이미 편광특성과 단일모드 동작 특성이 확인 된 상용 내부 반사경형 $543 \mathrm{~nm}$ 헬륨네온 레이저관[7]을 포화흡수분광 실험에 사용하였다. 먼저 레이저의 주파수 안정을 위한 준비작업으로 안정화 궤환회로의 정수를 결 정하기 위해서 변조도와 변조주파수폭을 측정하였으며, 요오드셀 진공봉입장치를 제작하여 주파수 기준선으로 사용할 요오드셀을 제작하였다. ${ }^{127} \mathrm{I}_{2}$ 포화흡수분광을 하 여 초미세구조들의 3차 고조파 신호를 얻었으며, 이 3차 고조파 신호를 이용하여 헬륨네온 레이저의 주파수를 요 오드 포화흡수선의 중심에 안정화시킬 수 있었다.

\section{2. 실험}

\section{1 단일모드 $543 \mathrm{~nm}$ 헬륨네온 레이저의 변 조 및 제어소자 제작}

레이저 주파수를 요오드 분자의 포화흡수선에 안정화 하기 위해서는 포화흡수형의 분광곡선으로부터 분산형 신호를 얻어야 한다[8]. 레이저 출력곡선 $\mathrm{P}(\nu)$ 의 1 차 미 분신호를 얻거나 3 차 미분신호를 검출하면 분산형 신호 를 얻을 수 있다. Wallard에 의하면 3차 미분신호를 이용
하는 방법이 1 차 미분신호를 이용하는 것보다 출력배경 에 의한 레이저 주파수 옵셋 효과를 줄일 수 있으므로 주 파수 안정도를 더 높일 수 있다[9]. 3차 미분신호를 얻기 위해서 곡선 $\mathrm{P}(\nu)$ 를 주파수 변조하여야 한다. 주파수 변 조에서 안정도를 높이려면 최적 변조폭을 선택하여야 한 다. 요오드 분자의 흡수선폭이 $4 \sim 5 \mathrm{MHz}$ 이므로 최적 변 조폭을 $6 \mathrm{MHz}$ 로 하는 것이 좋다[10].

사용한 레이저의 변조폭을 알기 위해서 압전소자에 가 해준 변조신호폭과 압전소자의 압전상수로부터 계산된 최대 변형량 $\Delta \mathrm{L}$ 을 사용하면 다음식으로부터 변조폭 $\Delta \nu$ 를 계산할 수 있다.

$$
\Delta \nu=-\nu \frac{\Delta \mathrm{L}}{\mathrm{L}}
$$

그러나 변조용 압전소자를 레이저관에 부착할 때 에폭 시와 같은 접착제를 사용하기 때문에 압전소자의 변형량 이 레이저관에 $100 \%$ 전달되지 않는다. 따라서 실험에서 실제 변형량을 정밀하게 구하는 것이 어려우므로 직접 변조폭을 구하기 위하여, 그림 1 과 같은 장치를 사용하여 고주파 스펙트럼 분석기(RF-SA)로 광헤테로다인 맥놀이 신호를 측정하였다.

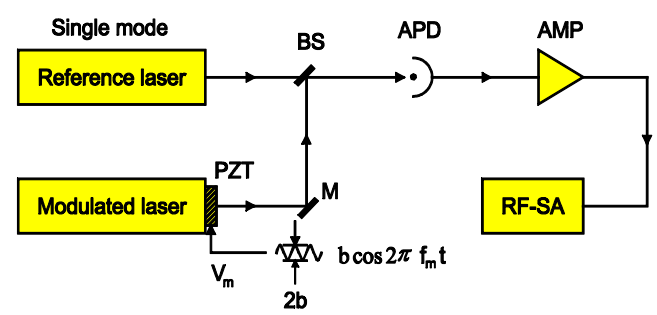

[그림 1] 주파수변조 폭 측정을 위한 실험 구성. 도. $\mathrm{M}$ : mirror, BS: beam splitter, APD: avalanche photodiode, AMP: RF-amplifier, RF-SA: RF-spectrum analyzer.

\section{2 요오드 진공봉입 장치 및 요오드셀 제작}

고순도의 ${ }^{127} \mathrm{I}_{2}$ 를 진공봉입한 요오드셀을 제작하였 다. 광학창이 양 끝에 부착된 용융 석영관셀을 독일 Hella 사에서 구입하여 정밀 세척하여 사용하였다. 이 셀 내부 에 요오드분자를 진공봉입하기 위하여 pyrex 유리로 만 든 전용 진공봉입 장치를 제작하였으며, $1 \times 10^{-7}$ torr 진공 분위기에서 요오드분자를 봉입하였다. Merck 사의 분광 용 고순도(Suparpur ${ }^{\square}$ ) 입자형 요오드분자를 구입하여 사 용하였다. 요오드셀의 진공봉입에서는 무엇보다도 $\mathrm{H}_{2} \mathrm{O}$ 와 $\mathrm{I}_{2}$ 를 분리하여 봉입하는 것이 중요하므로 이들 분자를 
분리 흡착하는 molecular sieves $4 \mathrm{~A}$ (일본 소화화학사)를 진공봉입장치에 있는 2 개의 trap에 넣어 사용하였다.

용융 석영셀에 요오드 분자를 진공봉입한 후 $543 \mathrm{~nm}$ 헬륨네온 레이저 광으로 조사하여 육안으로 형광을 조사 하였다. 육안 형광측정실험을 통해서 형광이 잘 되고 있 음과 형광의 변화에 의해 강한 흡수선도 존재함을 통하 여 요오드 분자의 진공봉입이 잘 된 것을 알 수 있었으 나, 제작된 셀을 사용하여 안정화 레이저를 구성하여 그 주파수 옵셋을 측정한 후에서야 요오드셀 진공봉입 장치 의 절대적 성능을 판정할 수 있다.

\section{$2.3543 \mathrm{~nm}$ 의 $\mathrm{He}-\mathrm{Ne}$ 레이저를 이용한 $\mathrm{I}_{2}$ 의 포화흡수분광 장치 제작}

$543 \mathrm{~nm}$ 에서의 요오드의 흡수계수가 $633 \mathrm{~nm}$ 에서의 흡 수계수보다 훨씬 크다. 그러므로 낮은 압력의 외부 요오 드셀에서 저출력 레이저빔을 사용하여도 충분히 강한 흡 수분광을 볼 수 있다. 이러한 특성 때문에 흡수분광선의 선폭확대와 이동을 억제할 수 있으며, 외부 셀에서 레이 저빔의 파전면을 정확히 조절함으로써 레이저빔의 기하 면 효과와 파전면 효과로 인한 도플러 선폭을 제거할 수 있어서 주파수 표준화에 큰 도움을 준다[11].

포화흡수분광을 위한 실험장치를 그림 2에 보였다. 자 석은 레이저관에 횡자장을 걸어서 편광 불안정을 없애주 는 역할을 하고, 편광판(P)을 레이저관의 고유광축과 일 치시키면 직교 2-모드에서 고유광축에 나란한 모드만 통 과시키고 이웃하는 직교모드를 제거함으로써 단일 편광 모드만을 선택할 수 있다. 이 두 가지를 결합시키면 단일 모드 FSR(free spectral range) 동작을 $440 \mathrm{MHz}$ 에서 880 $\mathrm{MHz}$ 의 두 배로 확대시킬 수 있게 되고, 따라서 $\mathrm{R}(12)$ 26-0에서 10 개와 R(106) 28-0에서 10 개의 요오드 흡수 스펙트럼선을 안정적으로 얻을 수 있다.

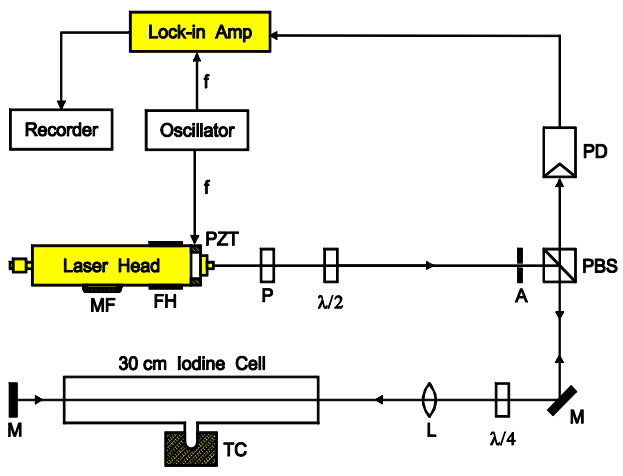

[그림 2] 포화흡수 분광으로 ${ }^{127} \mathrm{I}_{2}$ 의 초미세 스펙트럼 관 찰을 위한 포화흡수분광 실험 장치 구성.
P: linear polarizer, $\lambda / 2$ : half-wave plate, A: aperture, PBS: polarizing beam splitter, $\mathrm{M}$ : mirror, $\lambda / 4$ : quter-wave plate, L: lens for beam expansion, TC: temperature controller, PD: photodiode.

단일모드에서 얻어진 최대 출력은 $300 \mu \mathrm{W}$ 였으며, 편 광판(P)의 축에 대해 반파장판 $(\lambda / 2)$ 을 회전시키면 편광 면이 회전하게 되고, 회전 편광면과 편광분리기(PBS)의 결합은 가변감쇠기가 된다. 따라서 출력을 연속적으로 감 쇠 조절할 수 있으므로 적절한 출력세기를 갖는 레이저 빔을 외부 요오드셀에 입사시킬 수 있다.

편광분리와 4 분파장판 $(\lambda / 4)$ 의 결합은 제 2 의 광격리기 로 사용되어 요오드셀의 반사경으로부터 반사된 레이저 빔이 레이저관을 향하여 되돌아가는 것을 방지한다. 빔확 대기 $(\mathrm{L})$ 는 파전면 효과와 기하면 효과를 사용하여 요오 드 매질에 존재하는 도플러 선폭확대를 줄이기 위하여 삽입되었다[11]. 구경(A)는 광정렬과 배경광 제거 및 광 학소자와 포토다이오드로부터 산란되어 되돌아오는 빔을 방지하기 위해 사용하였다.

용융 석영관으로 제작한 직경 $25 \mathrm{~mm}$ 이고 길이 $30 \mathrm{~cm}$ 인 외부 요오드셀을 사용하였다. 펠티어 소자와 AD590 온도감지 IC의 조합으로 구성된 전자온도 제어장치를 사 용하여 냉지(cold finger)의 온도를 조절하였다. 분광실험 할 때 냉지의 온도를 $0{ }^{\circ} \mathrm{C}$ 로 유지함으로써 요오드 증기압 력을 4.5 Pa로 유지할 수 있었다[12]. 이러한 요오드 증기 압력에서 $543 \mathrm{~nm} \mathrm{He}-\mathrm{Ne}$ 레이저 선에 대한 ${ }^{127} \mathrm{I}_{2}$ 의 전형 적인 도플러 선폭은 $1.6 \mathrm{GHz}$ 이다. 그것은 $\mathrm{B}^{3} \Pi-\mathrm{X}^{1} \Sigma$ 계의 회전준위 $\mathrm{R}(12)$ 26-0과 $\mathrm{R}(106)$ 28-0와 일치하며, 각각의 회전준위는 15 개의 초미세구조 성분을 갖는다[2].

레이저관에 부착시킨 열선(FH)과 압전소자(PZT)의 전 압을 조절함으로써 레이저관의 길이를 변화시킬 수 있으 며, 길이의 변화는 레이저 출력의 주파수 변화로 나타나 게 된다. 먼저 열선의 전압을 제어하여 레이저 출력 주파 수의 흐름을 정지시킨 후 압전소자에 고전압을 가하면 레이저 주파수를 원하는 주파수 대역만큼 주사시킬 수 있으며, 이 때 주사되는 레이저의 출력 주파수가 요오드 분자의 흡수선의 중심과 일치할 때 나오는 포화흡수신호 로부터 변조용 압전소자(PZT)와 록인(lock-in) 증폭기를 사용하여 3 차 고조파 포화흡수신호를 얻을 수 있었다.

\section{4 요오드 안정화 $543 \mathrm{~nm}$ 헬륨네온 레이저 장치 제작}

요오드 안정화 헬륨네온 레이저 장치는 1) 레이저관, 
변조 및 제어용 압전소자, 빔전송 광학계, 단일모드 선택 용 횡자석 및 편광소자, 레이저광 격리용 $\mathrm{AO}$ 변조기, 레 이저 분광기를 형성하는 광학계, 요오드셀, 광검출기 등 을 포함하는 레이저 광학계, 2) 광검출기에서 검출된 신 호로부터 변조 신호 및 제어신호를 만들어내고 광의 스 펙트럼을 분석 할 수 있는 광스펙트럼 분석기용의 전자 장치, 요오드 셀의 온도를 자동제어하는 제어전자계 및 레이저의 전원을 공급하는 전원장치 등을 포함하는 전자 제어계로 구성된다.

$543 \mathrm{~nm}$ 헬륨네온 레이저의 낮은 이득 특성으로 인하 여 외부셀형의 요오드 안정화 헬륨네온 레이저를 구성하 였다. 공진기의 외부에 요오드셀을 설치한 외부셀 방식의 요오드 안정화 헬륨네온 레이저 장치의 구조를 그림 3 에 보였다.

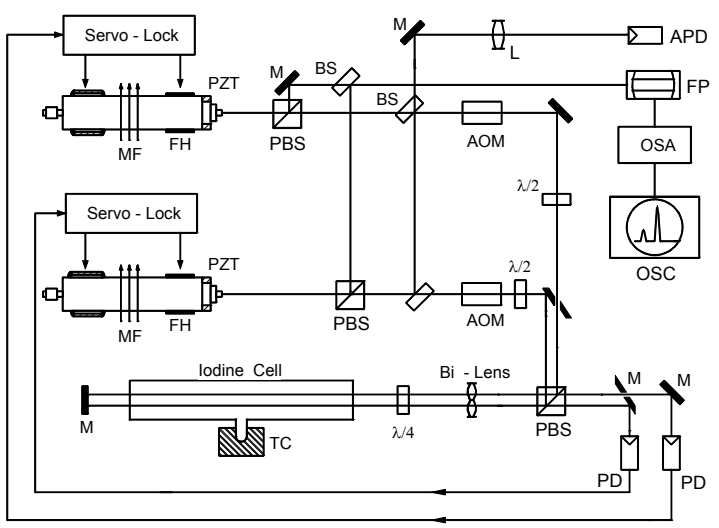

[그림 3] 요오드 안정화 $543 \mathrm{~nm}$ 헬륨네온 레이저 장치 구 조.

레이저 광학계는 포화흡수분광 장치와 대부분 동일하 다. 레이저 안정화를 위하여 포화흡수분광 장치에 추가적 으로 부가된 광음향변조기(AOM)는 요오드셀의 반사경 에서 반사되어 나오는 빛이나 $\mathrm{AOM}$ 과 요오드셀의 반사 경 사이에 있는 광소자들로부터 반사되거나 산란된 빛들 이 레이저관으로 되돌아와서 간섭을 주는 것을 방지하는 광격리기(optical isolator)역할을 한다. $\mathrm{AOM}$ 을 $80 \mathrm{MHz}$ 의 주파수로 변조하면 회절격자로 작용하여 입사 레이저 빔에 대하여 1차 회절된 레이저빔을 출력시키므로 되돌 아오는 빛은 레이저빔이 이미 진행한 경로를 역으로 그 대로 따라 올 수 없게 되고 되돌아오더라도 레이저의 중 심주파수에 $80 \mathrm{MHz}$ 의 이동이 생겨나기 때문에 진행 레 이저빔과 간섭을 일으키지 않는다.

전자제어계는 포화흡수분광 장치와 크게 다르다. 레이 저를 주파수 변조폭 4 6 $\mathrm{MHz}$ 정도로 변조하기 위하여 레이저 출력경에 부착한 원통형의 압전소자(PZT)의 공진
주파수를 이용하는 것이 낮은 전압으로도 변조 가능하며 민감하고 효율적이다. 이 때의 변조주파수를 $\mathrm{fm}(\mathrm{Hz})$ 이라 고 하면 요오드 분자의 포화흡수분광을 위하여 변조된 레이저 출력광의 3 차 $(3 \mathrm{fm})$ 고조파 신호를 검출하기 위하 여 변조주파수의 3 차 고조파 검출용의 위상민감검출기 (PSD)를 전자제어 장치에 포함시켰다. 변조주파수의 3차 고조파 신호를 $\mathrm{PSD}$ 의 기준신호로 하였으며, 변조된 레이 저 출력을 광검출기(PD)로 검출한 신호를 입력신호로 하 였다. PSD에서 검출된 출력신호는 요오드 흡수선의 위상 정보를 가지므로 레이저 주파수 제어용 신호로 사용할 수 있다. 이 제어 신호는 PI 제어회로와 actuator 제어 증 폭기를 통하여 레이저관에 부착된 대형 압전소자(PZT)와 열선(FH)에 인가된다. 이 인가전압이 압전소자를 변형하 고 열선에 의해 레이저 공진기의 길이를 제어시키게 되 어 요오드의 초미세구조선의 포화흡수신호의 공진 첨두 치 즉, $3 \mathrm{fm}$ 신호전압이 0이 되는 값에서 레이저 주파수가 제어되도록 제어루프를 구성하였다.

\section{3. 결과 및 논의}

그림 1 의 단일모드 $543 \mathrm{~nm}$ 헬륨네온 레이저의 변조 실험장치에서 압전소자에 가한 변조 전압신호 $\left(\mathrm{V}_{\mathrm{m}}=\right.$ $\mathrm{b} \cos 2 \pi f_{m} t$ )에 대한 레이저 맥놀이 신호의 선폭을 측 정한 것을 그림 4 에 나타내었다. 이 때 변조신호의 첨두 치 전압진폭(2b)에 비례하는 맥놀이 신호의 선폭(2a)은 변조폭에 해당한다[13].

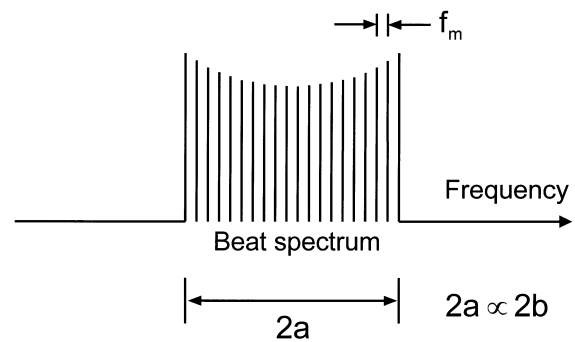

[그림 4] 광학적 헤테로다인에 의해 변조된 레이저의 맥놀 이-스펙트럼.

압전소자에 거는 전압으로부터 직접 변조폭을 환산할 수 있는 변조효율을 측정할 필요가 있다.[11] 변조효율을 측정하기 위해서, 먼저 변조 주파수에 따른 압전소자와 레이저관의 결합으로 구성된 레이저 변조기의 기계적 공 진특성을 측정하여야 한다[14]. 변조전압을 $10 \mathrm{Vp}$-p로 고 정하고 변조 주파수를 $100 \mathrm{~Hz}$ 에서 $3 \mathrm{kHz}$ 까지 가변 하였 
을 때 측정한 공진특성을 그림 5 에 나타내었다. 공진 최 대 변조 주파수는 $2.5 \mathrm{kHz}$ 이고, 이 때 변조효율이 가장 좋다. $2.5 \mathrm{kHz}$ 에서 측정한 변조기의 레이저관에 대한 구 동감도(actuating sensitivity)는 $1.9 \mathrm{~nm} / \mathrm{V}$ 이다.

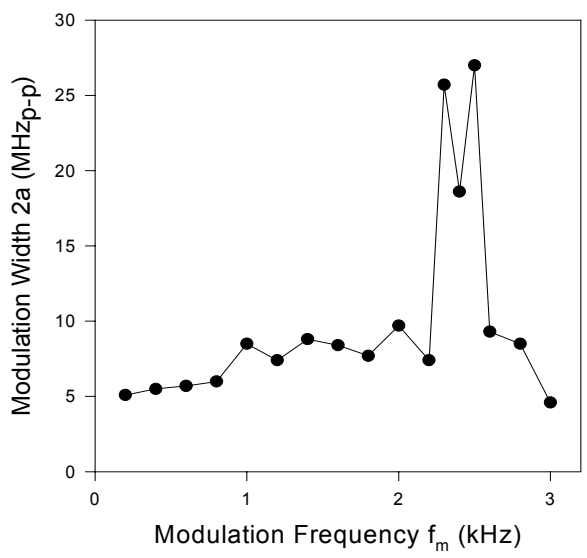

[그림 5] 레이저 공명기의 기계적 공명 특성.

변조 주파수를 $2.5 \mathrm{kHz}$ 에 고정시킨 상태에서 변조전 압 0 12 Vp-p에 대한 변조폭의 변화를 측정한 것을 그 림 6에 보였다. 그림에서 직선의 기울기가 변조효율을 나 타내는데 $2.5 \mathrm{MHz} / \mathrm{V}$ 이다. 그러므로 요오드 흡수분광을 위한 레이저 공진기에서 최적 변조를 얻기 위해서는 주 파수가 $2.5 \mathrm{kHz}$ 이며 전압이 $2.5 \mathrm{Vp}-\mathrm{p}$ 인 변조신호를 압전 소자에 가해 주어야 한다.

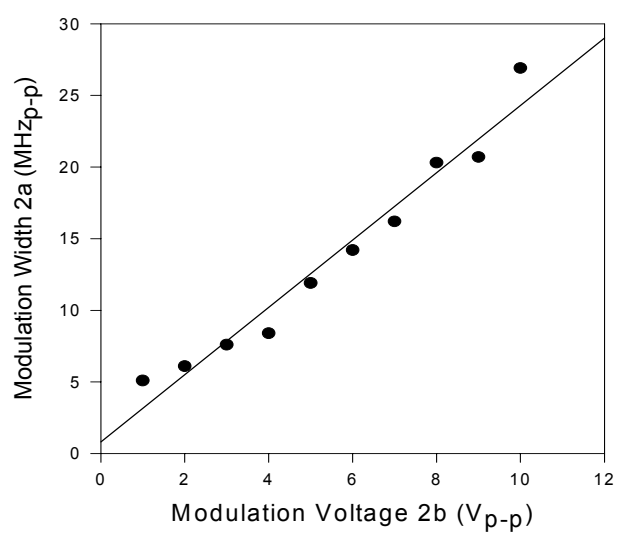

[그림 6] 변조 효율 특성
레이저 동조를 동시에 사용하여 3차 고조파 포화흡수분 광을 하였으며, 그림 7과 같은 결과를 얻었다.

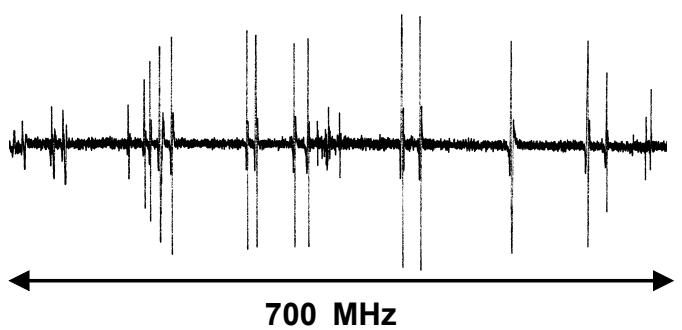

[그림 7] PZT와 열 동조를 사용한 레이저 공명기 길이 변 화에 따른 초미세 스펙트럼의 3차 조화파 특성.

이것은 두 개의 서로 다른 열적 동조범위를 조합한 것 이다. 아주 강한 천이들을 볼 수 있는데, 이 천이들은 $\Delta \mathrm{F}=\Delta \mathrm{J}=+1$ 에 해당한다. 각각 관측된 성분들을 Gläser 가 사용한 명칭을 사용하여 표현하였으며, $\mathrm{a}$ 와 $\mathrm{b}$ 는 각각 $\mathrm{R}(12)$ 와 $\mathrm{R}(106)$ 의 성분을 나타낸다. 측정한 초미세 스펙 트럼은 Gläser의 이론[15]을 사용한 계산결과인 그림 8과 잘 일치하였다. 각 성분들의 최대값들을 연결한 포락선은 레이저 출력의 단일모드 휩씀영역 $(880 \mathrm{MHz})$ 에 해당한다 [3]. 변조폭 $3.5 \mathrm{MHz}$ 에서 선폭은 약 $4 \mathrm{MHz}$ 이다. 이로부 터 3차 선모양이 변조폭의 함수임을 알 수 있다. 무변조 때에 $\mathrm{I}_{2}$ 초미세선의 $\mathrm{FWHM}$ 선폭은 약 $1.8 \mathrm{MHz}$ 였다. 이 선폭은 수명-선폭확대 때문에 생긴 것으로 추정된다. 3 차 미분에서 $\mathrm{S} / \mathrm{N}$ 비는 약 $30: 1$ 로 얻어졌다.

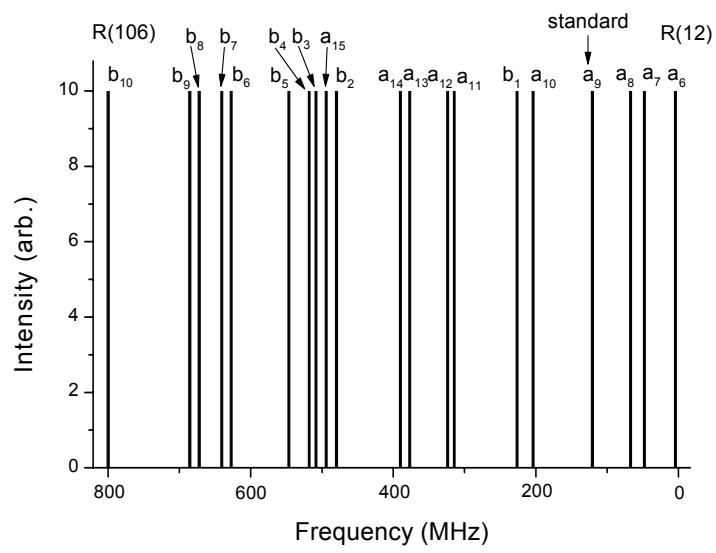

[그림 8] ${ }^{127} \mathrm{I}_{2}$ B-X 시스템의 $\mathrm{R}(12) 26-0$ 와 $\mathrm{R}(106) 28-0$ 천 이에 따른 초미세 스펙트럼 


\section{4. 결론}

본 연구를 통하여 $543 \mathrm{~nm}$ (녹색) 헬륨네온 레이저의 주 파수 안정화를 위하여 요오드 분자 $\left({ }^{127} \mathrm{I}_{2}\right)$ 를 이용한 포화 흡수 분광장치를 제작하여 파장 $543 \mathrm{~nm}$ 근방에서 $\mathrm{R}(106)$ 28-0 및 R(12) 26-0 천이선의 초미세 구조들의 3차 고조 파 신호를 관측하였다.

레이저 주파수를 변조하기 위하여 원통형의 압전소자 를 레이저관 둘레에 부착하여 그 공진주파수를 측정하고 단위 전압당 레이저 주파수 변조 최대진폭을 측정하였다. 공진주파수는 $2.3 \mathrm{kHz}$ 및 $2.5 \mathrm{kHz}$ 임을 알 수가 있었고, 측정된 변조효율은 $2.5 \mathrm{kHz}$ 에서 $2.5 \mathrm{MHz} / \mathrm{V}$ 였다. 레이저 주파수 변조폭 $6 \mathrm{MHz}$, 요오드 셀의 온도 $0{ }^{\circ} \mathrm{C}$, 단일 모드 출력 $300 \mu \mathrm{W}$ 에서 요오드 흡수선의 3 차 고조파 분광신 호를 측정하였으며, 위상민감검출기의 적분시정수 100

$\mu \mathrm{S}$, 감도 $10 \mathrm{mV}$ 에서 $30: 1$ 의 $\mathrm{S} / \mathrm{N}$ 비를 갖는 3 차 고조 파 신호를 검출하였다. 요오드 분자의 미세구조 $\left({ }^{127} \mathrm{I}_{2}\right.$, $\mathrm{B}^{3} \Pi-\mathrm{X}^{1} \Sigma, \mathrm{R}(12) 26-0$ and $\mathrm{R}(106)$ 28-0)중에 포함 되는 20 개의 초미세구조선 $\left(\mathrm{a}_{6}, \mathrm{a}_{7}, \mathrm{a}_{8}, \mathrm{a}_{9}, \mathrm{a}_{10}, \mathrm{a}_{11}\right.$, $a_{12}, a_{13}, a_{14}, a_{15}(R(12) 26-0), b_{1}, b_{2}, b_{3}, b_{4}, b_{5}, b_{6}, b_{7}$, $\left.\mathrm{b}_{8}, \mathrm{~b}_{9}, \mathrm{~b}_{10}(\mathrm{R}(106) 28-0)\right)$ 을 분광하였다.

앞으로, 관측된 요오드 분자 초미세구조선의 분광선을 이용하여 각 파장에서 같은 초미세구조선에 안정화되는 요오드 안정화 레이저를 2대 제작하고, 이들의 맥놀이 신 호로부터 요오드 분자의 초미세구조선간의 간격을 측정 하여 초미세 상호작용 상수들을 구하고자 한다. 더불어 2 대 레이저 사이의 주파수 옵셋, 안정도, 각 변수에 따른 주파수 편이 등의 측정으로 안정화 레이저의 주파수 특 성을 파악하여 녹색에서의 광주파수 표준을 확립하고 국 제 비교연구를 통하여 주파수 재현성 등을 확인하고자 한다.

\section{참고문헌}

[1] W. Luhs, B. Struve, and G. Litfin, "Durchstimmbarer Multilinien HeNe-Laser," Laser und Optoelektronik, Nr. 4, pp. 319-357, 1986.

[2] J. M. Chartier, J. L. Hall, and M. Gläser, "Identification of the I2 saturated absorption lines excited at $543 \mathrm{~nm}$ with the external beam of the green He-Ne laser," Porc. CPEM '86, ISBN 86CH2267-3, pp. 323-324, 1986.
[3] J. M. Chartier, S. Fredin-Picard, and L. Robertsson, "Frequency-stabilized $543 \mathrm{~nm} \mathrm{HeNe}$ laser systems: A new candidate for the realization of the metre?" Opt. Commun., vol. 74, no. 1,2, pp. 87-92, 1989.

[4] U. Brand, "Frequency stabilization of a HeNe laser at $543.5 \mathrm{~nm}$ wavelength using frequency-modulation spectroscopy," Opt. Commun., vol. 100, no. 1,2,3,4, pp. 361-373, 1993.

[5] H. Simonsen, and O. Poulsen, "Frequency stabilization of an internal mirror $\mathrm{HeNe}$ laser at $543.5 \mathrm{~nm}$ to I2-saturated absorptions," Appl. Phys. B, vol. 50, pp. 7-12, 1990.

[6] T. J. Quinn, "Mise en Pratique of the Definition of Metre(1992)," Metrologia, vol. 30, pp. 523-541, 1994.

[7] 김경찬, 서호성, 엄태봉, "내부 반사경 $543 \mathrm{~nm}$ 헬륨 네온 레이저의 편광특성과 단일모드 동작," 한국광학 회지, 제 9권 6호, pp. 403-407, 1998.

[8] W. Demtröder, Laser Spectroscopy 2nd Ed.(Springer-Verlag, Berlin, 1996), Chapter 6.

[9] A. J. Wallard, "The reproducibility of $633 \mathrm{~nm}$ lasers stabilized by 127I2," IEEE Trans. Instrum. Meas., vol. IM-23, pp. 532-535, 1974.

[10] BIPM, "Documents Concerning the New Definition of the Metre," Metrologia, vol. 19, pp. 163-177, 1984.

[11] T. Ishibashi, M. Yamashita, T. Tako, and Y. C. Li, "Frequency Locking of $543 \mathrm{~nm} \mathrm{He}-\mathrm{Ne}$ laser on Iodine Spectrum," Jpn. J. Appl. Phys., vol. 33 no. 3, pp. 1645-1647, 1994.

[12] T. J. Quinn and J. M. Chartier, "A New Type of Iodine Cell for Stabilized Lasers," IEEE Trans. Instrum. Meas., vol. IM-42, pp. 405-406, 1993.

[13] 서호성, 광주파수 표준용 $\mathrm{He}-\mathrm{Ne}$ 레이저 주파수 안 정화에 관한 연구(영남대학교 박사학위논문, 1993), pp. 89-91.

[14] N. Mio and K. Tsubono, "Frequency Modulation Method for a He-Ne Laser Using the Mechanical Resonance of the Laser Cavity," Jpn. J. Appl. Phys., vol. 29, no. 5, pp. 883-884, 1990.

[15] M. Gläser, "Hyperfine Components of Iodine for Optical Frequency standards," PTB Bericht, vol. opt-21, pp. 29-30, 1987. 


\section{김 경 찬(Kyung-Chan $\mathrm{Kim})$}

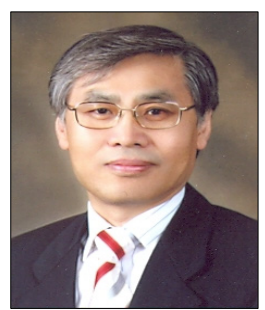

- 1978년 2월 : 경북대학교 물리학 과 (이학사)

- 1980년 8월 : 경북대학교 대학원 물리학과 (이학석사)

- 1988년 2월 : 경북대학교 대학원 물리학과 (이학박사)

- 1983년 3월 : 계명대학교 자연과 학대학 물리학과, 화학과 (교수)

<관심분야>

광학계 설계, 광학센서, u-Healthcare

\section{엄 년 식(Nyeon-Sik Eum)}

[정회원]

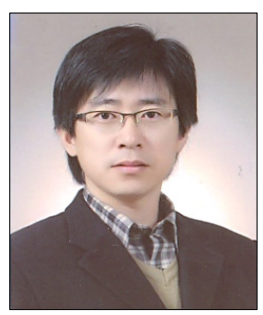

- 2004년 2월 : 경북대학교 대학원 센서공학과 (공학박사)

- 2009년 9월 : 계명대학교 의료기 기인재양성센터 (연구교수)

- 2009년 9월 : (주) 유바이오메드 (UBioMed Inc.) (대표이사)

<관심분야>

광센서, 이미징, u-needle, 바이오칩, SPR

홍 주 현(Joo-Hyun Hong)

[정회원]

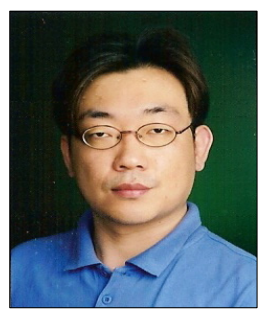

- 2001년 2월 : 단국대학교 전자공 학과 (공학사)

- 2003년 2월 : 충북대학교 대학원 의용생체공학과 (공학석사)

- 2008년 2월 : 충북대학교 대학원 의용생체공학과 (공학박사)

- 2009년 9월 : 계명대학교 의료기 기인재양성센터 (연구교수)

<관심분야>

임베디드 시스템 설계, u-Healthcare 장치 설계,

서 호 성(Ho-Sung Seo)

[정회원]

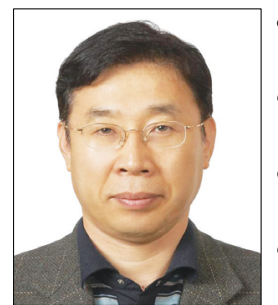

<관심분야>

레이저 광주파수, 장거리측정 및 측량측정
- 1980년 2월 : 영남대학교 물리학 과 (이학사)

- 1982년 3월 : 경북대학교 대학원 물리학과 (이학석사)

- 1994년 2월 : 영남대학교 대학원 물리학과 (이학박사)

- 1982년 4월 : 한국표준과학연구 원 길이연구실장, 정보통신표준 센터장, 국가참조표준센터장 (책 임연구원) 